$$
S F=53
$$




$$
\mathrm{H}^{\mathrm{d}}
$$

จ. 
UNITED STATES DEPARTMENT OF AGRICULTURE

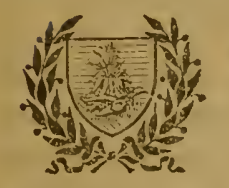

BULLETIN No. 944

Contribution from the Bureau of Animal Industry JOHN R. MOHLER, Chief

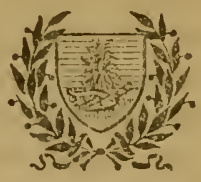

Washington, D. C.

Miay 12,1921

\section{THE ALCOHOL TEST AS A MEANS OF DETERMIN- ING QUALITY OF MILK FOR CONDENSERIES.}

By A. O. Damlberg and H. S. Garxer, Rescarch Laboratorics, Duiry Dirision.

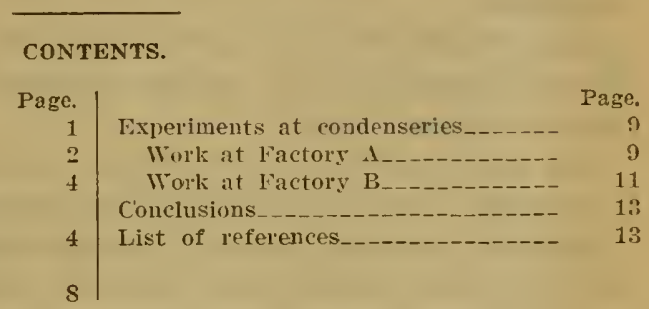

\section{REVIEW OF PREVIOUS WORK.}

The urgent necessity for some means of determining the quality of milk receired at condenseries and other dairy manufacturing plants has resulted in the continued use of the acid test even after its defects have become generally recognized. This test is based on the assumption that a titratable acidity above the normal for fresh milk indicates an increase in acidity due to bacterial action.

It is well known, however, that a certain part of the alkali added to milk to obtain an end point with any given indicator is combined with constituents of the milk other than the acids. While this has been recognized it has not been generally realized how great a variation in the apparent acidity may be due to this cause. It has been recently pointed out by Rice $(1)^{1}$ that the casein and the phosphates both combine with alkali and are subject to a sufficient variation to cause in some instances an apparent high acidity in fresh milk.

Our own experience, which is not unusual, has shown that not infrequently milk rejected because of high acidity was fresh milk in which bacterial action was highly improbable. In making evaporated milk the most essential characteristic is the ability of the milk

1 See list of references at end of bulletin.

$27179^{\circ}-21$

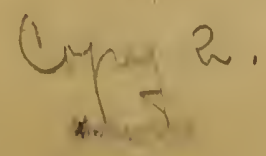


to withstand a temperature sufficiently high to insure the subsequent sterilization without causing an objectionable curd. While it is assumed, and no doubt correctly, that acidity is an important factor in determining the coagulating point of concentrated milk, it is by no means certain that other factors may not be of equal or even greater importance. Sommer and Hart (2) have shown that there is no consistent relation between the titratable acidity and the heat coagulating point of milk. This they found also to be true of the hydrogen-ion concentration or true acidity of the fresh milk, but they express the opinion that it may become a factor under commercial conditions. They found, on the other hand, that the variations which occur normally in certain of the ash constituents have an important part in determining the temperature at which it coagulates.

The titration of milk in the usual way will give no indication of the condition of the ash and may be very misleading as to the hydrogen-ion concentration.

The alcohol test has been used to a limited extent for determining the quality of milk with special reference to its sanitary condition.

This test is usually made by mixing equal volumes of milk with 68 to 75 per cent alcohol and observing wlether a coagulation results. It is generally considered that a coagulation indicates bacterial change in the milk, but Auzinger (3) shows that fresh milk not infrequently coagulates under these conditions and offers some evidence to show that it is due to changes in the milk salts, particularly in the calcium. Ayers and Johnson (4) show that while the alcohol test becomes positive when an appreciable amount of acid or rennet is produced in the milk there is no consistent relation between the alcohol test and the total number of bacteria present.

They found that while the addition of acid phosphates to milk increased the tendency to coagulate with alcohol, the neutral or dibasic phosphate had the opposite effect. When dibasic phosphate is added to milk considerably more acid is required to produce a positive alcohol test than with the normal milk.

While the work of Ayers and Johnson shows that the alcohol test is not a reliable index of the sanitary quality of the milk, there is a possibility that its action on milk may be correlated with the heat coagulation point of the evaporated milk in such a way as to render it of some value in grading milk in condenseries.

\section{TEST METHODS USED.}

The alcohol test as used in this investigation was made by mixing equal parts of 75 per cent alcohol and milk and observing whether coagulation takes place. In case the milk shows a visible coagulation

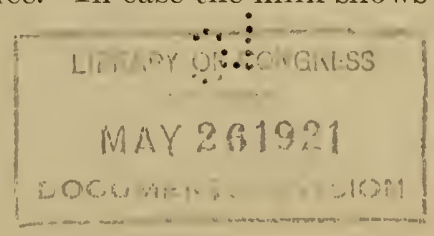


it is considered unsafe from the standpoint that the milk after evaporation will not stand the heat necessary for sterilization without becoming curdy. The test is practical and easy to make at the weigh room. The test as used in this work was made by adding 1 c. c. of milk to a small test tube containing 1 c. c. of alcohol and mixing at once by inverting once or twice while holding a finger over the top. Any reaction that takes place will be rery quickly eviclent, the large majority of tests showing coagulation immediately or giving no reaction at all. The gradation of coagulation is shown by the size of the curd particles formed. Unless the curd particles formed are small the reaction is not at all difficult to distinguish, even by one not familiar with the test. A mixture of milk and alcohol giving 'a negative reaction immediately breaks clear from the walls of the test tube, while a mixture giving a coagulation of fine particles will leave the walls of the test tube cloudy. Mixtures showing a medium or large particle curd formation are readily discernible because of the adherence of the curd particles to the walls of the test tube.

In the work of grading the milk at a condensery on a commercial basis two small brass dippers of 2 c. c. capacity each were used. Thirty test tubes arranged in a block of wood 3 inches wide, 2 inches deep, and 18 inches long, having three rows of holes of the proper diameter and depth, were first filled with 2 c. c. of the 75 per cent alcohol by means of one of the brass dippers. Two men working together then went through the individual cans, taking 2 c. c. of milk from each and mixing it with the $2 \mathrm{c}$. c. of alcohol. No more time was required than is necessary in making the acidity test.

The first work attempted with the alcohol test was to determine whether any correlation existed between the coagulation and the acid content of milk as measured by the usual titration method. Samples of milk were taken from individual patrons at the weigh room of the Grove City, Pa., creamery for the observations made. Reactions with 75 per cent ethyl alcohol and titratable acidity were determined shortly after taking samples and at stated intervals on those not showing positive coagulation with alcohol, until such action occurred. All samples which did not show coagulation with alcohol at the outset were held in a water bath at $35^{\circ}$ to $37^{\circ} \mathrm{C}$. $\left(95^{\circ}\right.$ to $98.6^{\circ}$ F.) during subsequent observations. A tabulation of 211 samples of milk handled according to the method outlined shows conclusively that there is no direct relation between the coagulation of the milk with 75 per cent alcohol and the acid content of milk as measured by the titration method. 


\section{EXPERIMENTS AT GROVE CITY CREAMERY.}

\section{COMPARISON OF ACIDITY AND ALCOHOL TESTS OF MILK FOR CONDENSING.}

Finding no consistent relation between the coagulation of milk by alcohol and its acidity content as shown by the titration method, work was started to ascertain the relative value of the two tests. Samples of milk, representing all conditions met with at the condensery, were taken at the weigh room of the Grove City creamery. Five pounds of each sample selected-which in the large majority of cases represented a mixed mills of some particular patron's herdwas evaporated in a 10-liter flask under a vacuum of 25 to 27 inches to a concentration of 21 to 1 , the time required being from 50 to 70 minutes, with a temperature of $40^{\circ}$ to $50^{\circ} \mathrm{C}$. $\left(104^{\circ}\right.$ to $122^{\circ} \mathrm{F}$.). The eraporated milk was placed in baby-size tins and sterilized in an autoclave for 30 -minute intervals at $121.1^{\circ}, 112.8^{\circ}$, and $107.2^{\circ} \mathrm{C}$. $\left(250^{\circ}, 235^{\circ}\right.$, and $225^{\circ} \mathrm{F}$. $)$. Portions of evaporated milk in 100 c. c. Erlenmeyer flasks were run in the autoclave at the temperatures used and also at $100^{\circ} \mathrm{C} .\left(212^{\circ} \mathrm{F}\right.$.) for 30 minutes to note the extent of coagulation. When sterilization at $112.8^{\circ}$ C. $\left(235^{\circ} \mathrm{F}\right.$.) for 30 minutes indicated that the product would not stand a higher processing, the next lower temperature was used, only two temperatures higher than $100^{\circ} \mathrm{C}$. $\left(212^{\circ} \mathrm{F}\right.$.) being used. The cooled cans of sterilized milk were shaken for one minute before examination for general physical appearance and curdiness.

The main observation of the sterilized samples of eraporated milk concerned the extent of coagulation and whether or not they showed curdiness after shaking. Curdiness of shaken samples was determined by the physical appearance of the product and by mixing a portion of it with hot water. In reporting on whether or not the sterilized samples were curdy after shaking, the temperature of $112.8^{\circ} \mathrm{C}$. $\left(235^{\circ} \mathrm{F}\right.$.) for 30 minutes was used as a standard of comparison. In the large majority of instances the curdiness was pronounced enough to leave no donbt as to the accuracy of decision, and the sample sterilized at the lower temperature quite generally substantiated the classification given on the basis of the standard temperature used. On the other hand, the samples showing no curdiness after sterilization were in most cases not at all difficult to classify, as they showed, in general, less coagulation even with the higher temperature.

Table 1 shows the results of sterilization of 90 samples of milk of varying acidity, 45 of which coagulated with 75 per cent alcohol. Forty-three of the 45 when evaporated and sterilized at $112.8^{\circ} \mathrm{C}$. $\left(235^{\circ} \mathrm{F}\right.$.) for 30 minutes showed curdiness after shaking. Coagulation of practically all these samples when evaporated was very pronounced, in some instances being so hard that it was impossible in 
any manner to reduce the extreme lumpiness. Some of the samples of low acidity showed as objectionable a curdiness as those of the higher acidity, indicating the reliability of the alcohol test and unreliability of the acid test in picking out those which will not stand the sterilization necessary in manufacturing evaporated milk.

The table shows also the result of sterilization upon 45 samples of milk of varying acidity, all of which showed a negative reaction with 75 per cent alcohol. Forty-two of the 45 when evaporated and sterilized showed no curdiness after shaking.

TARLE 1.-Comparison of alcohol and acid tests at Grove City creamery. wilk concentruted? 21 to 1 and sterilized at $235^{\circ} \mathrm{F}$. for 30 minutes. Effect of sterilization noted after shaking for 1 minute.

\begin{tabular}{|c|c|c|c|c|c|c|}
\hline \multirow{3}{*}{ Acidity. } & \multicolumn{3}{|c|}{$\begin{array}{l}\text { Coagulation with } 75 \text { per } \\
\text { cent alcohol. }\end{array}$} & \multicolumn{3}{|c|}{$\begin{array}{l}\text { No coagulation with } 75 \\
\text { per cent alcohol. }\end{array}$} \\
\hline & \multirow{2}{*}{$\begin{array}{c}\text { Total } \\
\text { samples. }\end{array}$} & \multicolumn{2}{|c|}{$\begin{array}{l}\text { Effect of steri- } \\
\text { lization. }\end{array}$} & \multirow{2}{*}{$\begin{array}{l}\text { Total } \\
\text { samples. }\end{array}$} & \multicolumn{2}{|c|}{$\begin{array}{l}\text { Effect of steri- } \\
\text { lization. }\end{array}$} \\
\hline & & Curdy. & $\begin{array}{l}\text { Not } \\
\text { curdy. }\end{array}$ & & Curdy. & $\begin{array}{l}\text { Not } \\
\text { curdy. }\end{array}$ \\
\hline \multirow{7}{*}{$\begin{array}{l}\text { Per cent. } \\
0.14 \text { to } 0.15 \\
.15 \text { to } .16 \\
.16 \text { to } .17 \\
.17 \text { to } .18 \\
.18 \text { to } .19 \\
.19 \text { to } .20 \\
.20 \text { to } .21\end{array}$} & 3 & 3 & 0 & & & \\
\hline & 5 & 5 & 0 & 1 & 0 & 1 \\
\hline & 10 & 8 & 2 & 99 & $\begin{array}{l}0 \\
1\end{array}$ & 99 \\
\hline & 10 & 10 & $\begin{array}{l}0 \\
0\end{array}$ & 11 & 1 & 10 \\
\hline & 5 & 5 & 0 & 10 & 0 & 10 \\
\hline & 1 & 1 & 0 & 2 & 1 & 1 \\
\hline & 45 & 43 & 2 & 45 & 3 & 42 \\
\hline
\end{tabular}

It seems quite certain that there is some condition of raw milk coagulating with 75 per cent alcohol, making it impossible to sterilize without getting a curdy finished product, for such milks when evaporated and sterilized give a much firmer coagulation than those showing a negative reaction with 75 per cent alcohol. In some instances the coagulation, even at the lower temperatures used, is such that the product turns to a hard, cheesy mass incapable of improvement with long-extended shaking. Figure 1 , showing the type of curd obtained in sterilization, indicates clearly the difference which must exist in the condition of milk coagulated with 75 per cent alcohol. Only 6.7 per cent of the samples made from milk coagulating with alcohol gave a soft curd, the remainder giving either a firm or a hard curd, both of which are as a rule difficult to shake out to give a product showing no curdiness. With the evaporated samples from raw milk not coagulating with 75 per cent alcohol 88.9 per cent gave either a soft curd or no coagulation at all, the remaining 11.1 per cent giving a firm curd. The soft curds shake out very easily, giving a smooth-bodied product of good consistency showing no curdiness. 
The difference in the effect of sterilization upon evaporated milk made from raw milk, showing negative or positive reaction with 75 per cent alcohol is further emphasized in figure 2, which shows the curdiness found at all temperatures used.

To get complete figures on all the four temperatures it was assumed in compiling these data that a sample showing curdiness at a. temperature actually used would show curdiness at any higher temperature. With raw milks showing negative reaction with 75 per

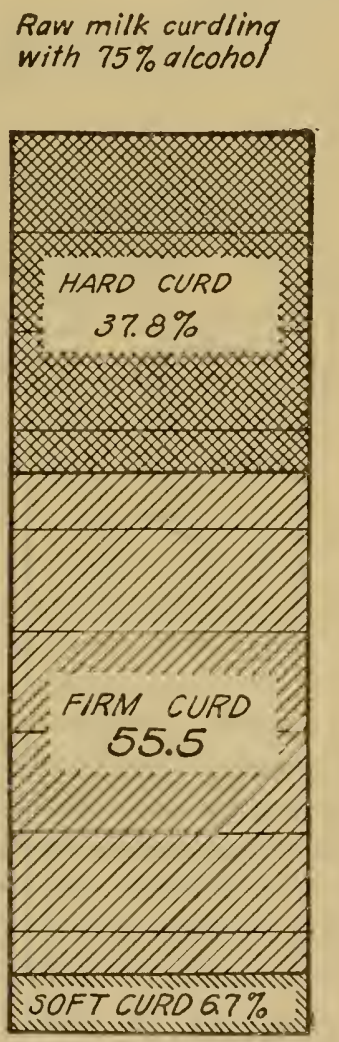

\section{Raw milk not curdling with $75 \%$ alcohol}

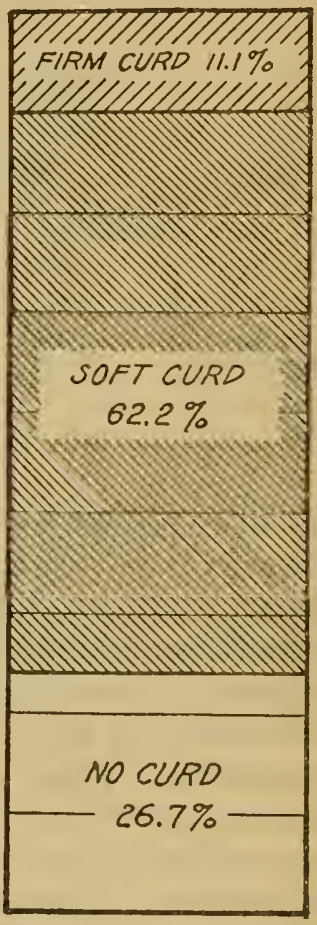

Fig. 1.-Types of curd obtained in sterilization of evaporated milk.

cent alcohol only 4.4 per cent of the evaporated samples showed curciness at $100^{\circ}$ C. $\left(212^{\circ} \mathrm{F}.\right)$ and $107.2^{\circ} \mathrm{C}$. $\left(225^{\circ} \mathrm{F}\right.$.) for 30 minutes; 6.6 per cent at $112.8^{\circ} \mathrm{C}$. (235 $\mathrm{F}$.) for 30 minutes; and 31.1 per cent at $121.1^{\circ} \mathrm{C}$. $\left(250^{\circ} \mathrm{F}\right.$.) for. 30 minutes. With raw milks coagulating with 75 per cent alcohol, 57.7 per cent showed curdiness at a temperature of $100^{\circ} \mathrm{C}$. $\left(212^{\circ} \mathrm{F}\right.$.) for 30 minutes, 80 per cent at $107.2^{\circ} \mathrm{C}$. (225 ${ }^{\circ} \mathrm{F}$.) for 30 minutes, 95.5 per cent at $112.8^{\circ}$ C. $\left(235^{\circ} \mathrm{F}\right.$.) for 30 minutes, and 100 per cent at $121.1^{\circ} \mathrm{C}$. $\left(250^{\circ} \mathrm{F}\right.$.) for 30 minutes. These figures show quite strikingly a difference in 
condition of milk coagulating with 75 per cent alcohol, which renders it impossible to manufacture from it evaporated milk that will not give curdiness when using a sterilizing temperature necessary to insure a complete destruction of the bacteria. Samples of raw milk giving a coagulation with alcohol and showing curdiness when evaporated and sterilized can be sterilized without showing curdiness

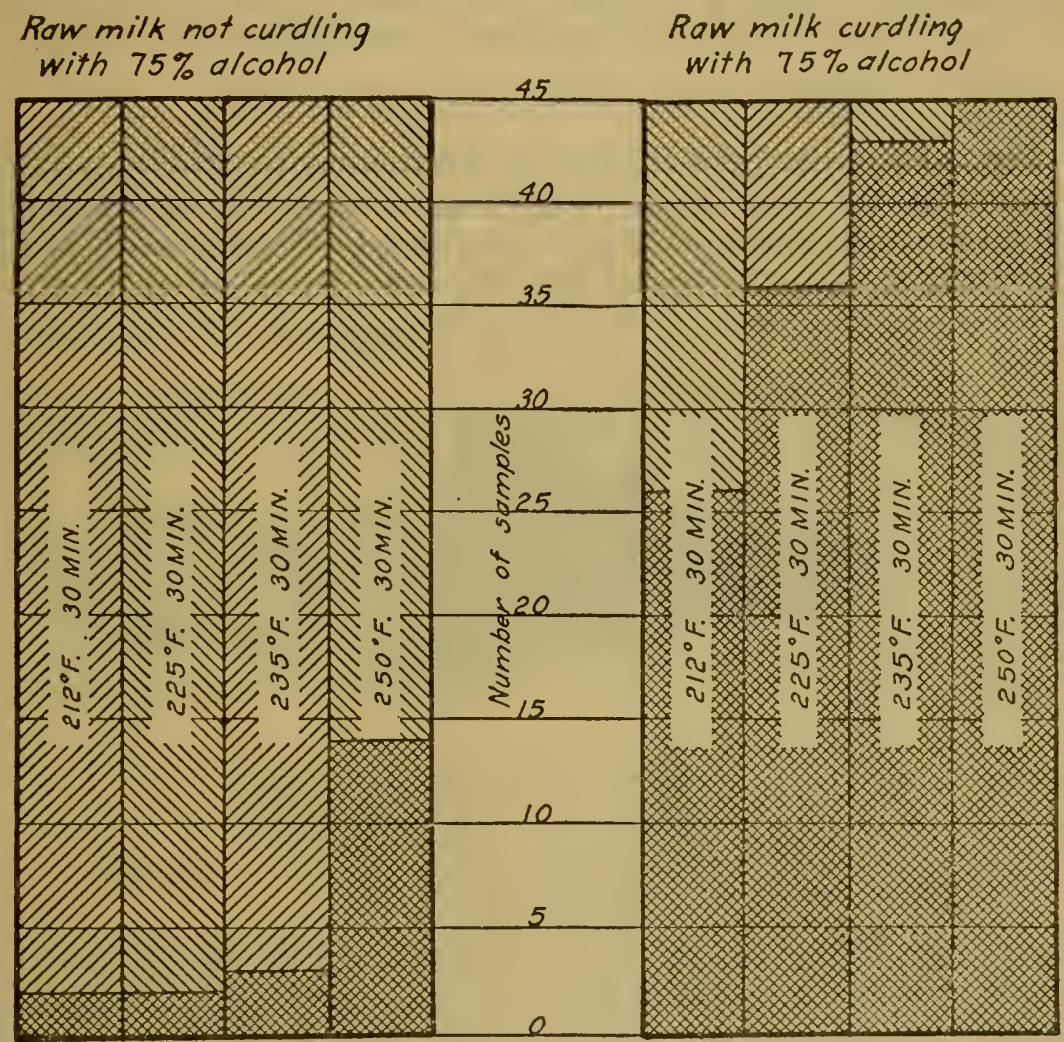

\section{No curdiness \\ Curdiness}

FIG. 2.-Extent of curdiness in evaporated milk sterilized at different temperatures.

of the finished product in a mixture containing from 60 to 70 per cent of raw millss giving a negative alcohol test. This fact would account for the variation in heat taken by different batches from day to day.

Undoubtedly there is received at every condensery some milk which will not stand the required heat when evaporated by itself, but which will go through all right when mixed with other milk. If the 
proportion of this milk is not too high no trouble will be experienced, but the proportion in some batches may be such as to cause considerable trouble.

It is interesting to know that raw milk with a low titratable acidity and which coagulates with alcohol and shows curdiness after eraporating and sterilizing can be made to stand sterilization with no resulting curdiness by mixing with it the proper amount of milk showing a high titratable acidity but no coagulation with alcohol.

\section{relative VAlUe of ACID AND AlCOHOL TESts.}

The value of any practical test for determining the quality of milk for condensing must depend largely upon its ability to determine whether or not that milk, when eraporated to the required density, will withstand the necessary sterilizing temperature without becom-

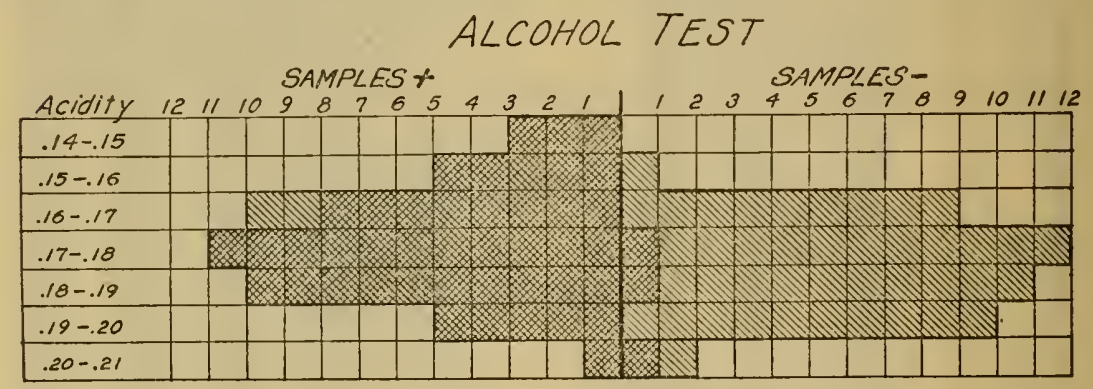

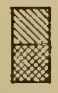

No curd at $235^{\circ} \mathrm{F}$ for $30 \mathrm{~min}$. curd at $235^{\circ} \mathrm{F}$. for $30 \mathrm{~m} / \mathrm{n}$.

Fic. 3.- The relation of titratable acjdity and the alcohol test to coagulation of the eraporated milk.

ing curdy. The flavor and odor are things which have to be determined by the senses of taste and smell. The tendency of milk with objectionable flavor and odor to coagulate with alcohol indicates additional value of the test from this standpoint, especially where little attention is given to these factors.

The preliminary work indicated clearly the unreliability of the acid test, as ordinarily used in the condensery, for determining the quality of milk for condensing. A comparison of the acid and alcohol tests in determining what milk when evaporated would stand sterilization without showing curdiness reveals the following:

Of 90 samples of raw milk taken at the-weigh room and representing a wide range of condition, 46 samples of the finished evaporated milk showed curdiness after sterilization and shaking. Fortyfour of the evaporated-milk samples withstood sterilization, showing no curdiness after shaking. Analysis of Table 2 and figure 3 shows that the alcohol test would have rejected 43 of the 46 samples 
that showed curdiness after sterilization and shaking, while it would have rejected 2 out of 44 that were all right; that is, showed no curdiness. The acid test would have rejected 18 of the 46 samples showing curdiness after sterilization and shaking, while it would have rejected 21 of the 44 that showed no curdiness.

The following tabulation shows the percentage of satisfactory and unsatisfactory milk samples that would have been retained or rejected by the alcohol and acidity tests:

Satisfactory milk samples retaine

Alcohol test. Acidity test. (1'er cent.) (1'er cent.)

Satisfactory milk samples rejected 9.5. 5

52.3

Unsatisfactory milk samples retained

4.5

47.7

Unsatisfactory milk samples rejected

6.5

60. 9

39. 1

Table 2 gives a more concrete comparison of the relative value of the alcohol and acid tests in the work done at Grove City, Pa.

TABLE 2.-Relative value of alcohol and acidity tests on samples run at Grove City, $P a$.

\begin{tabular}{|c|c|c|c|c|c|}
\hline \multirow{2}{*}{ Kind of samples. } & \multirow{2}{*}{$\begin{array}{l}\text { Number } \\
\text { of sam- } \\
\text { ples. }\end{array}$} & \multicolumn{2}{|c|}{ Alcohol test. } & \multicolumn{2}{|c|}{ Acidity test. } \\
\hline & & $\begin{array}{l}\text { Times } \\
\text { correct. }\end{array}$ & $\begin{array}{c}\text { Times } \\
\text { incorrect. }\end{array}$ & $\begin{array}{l}\text { Times } \\
\text { correct. }\end{array}$ & $\begin{array}{l}\text { Times } \\
\text { incorreet. }\end{array}$ \\
\hline $\begin{array}{l}\text { Satisfactory...... } \\
\text { Unsatisfactory... }\end{array}$ & $\begin{array}{l}44 \\
46\end{array}$ & $\begin{array}{l}42 \\
43\end{array}$ & $\begin{array}{l}2 \\
3\end{array}$ & $\begin{array}{l}21 \\
18\end{array}$ & $\begin{array}{l}23 \\
28\end{array}$ \\
\hline $\begin{array}{l}\text { Total......... } \\
\text { Per cent..... }\end{array}$ & $\begin{array}{r}90 \\
100\end{array}$ & $\begin{array}{r}85 \\
94.4\end{array}$ & 5.6 & $\begin{array}{r}39 \\
43.3\end{array}$ & $\begin{array}{r}51 \\
56.7\end{array}$ \\
\hline
\end{tabular}

EXPERIMENTS AT CONDENSERIES.

WORK AT FACTORY A.

Realizing the importance of trying out the alcohol test under other, including commercial, conditions, the work was extended to a condensery, which is designated as Factory $\mathbf{A},{ }^{2}$ where considerable difficulty had been experienced in making an evaporated milk meeting the requirements of 26.15 per cent total solids and 8 per cent fat. The small laboratory apparatus used in the Grove City work was set uip in the laboratory of this plant and work of the same nature as that done at Grove City carried on. Samples of individual patrons' milk showing positive or negative reaction with alcohol were condensed to bring the product as nearly as possible to 18.15 per cent solids not fat, that being the portion of the evaporated milk causing the difficulty in sterilization. It was the aim to have the samples that were eraporated from raw milk showing no coagulation with alcolol slightly above the point of 18.15 per cent solids not fat, and

2 The assistance of F. B. Evans in the work at this factory is acknowledged. 
those from raw milk showing coagulation with alcohol slightly below this point. Samples not showing close to this schedule are not included in the discussion of results.

The samples of evaporated milk put up in baby-size cans were run in a Berlin pilot sterilizer used by the plant in determining the amount of heat the different runs would stand.

The results of this work did not agree closely with those obtained at Grove City. All the samples of raw milk showing coagulation with alcohol gave an evaporated milk that showed curdiness after sterilization at a temperature of $112.8^{\circ} \mathrm{C} .\left(235^{\circ} \mathrm{F}\right.$.) for 30 minutes. As the samples of raw milk, showing no coagulation with alcohol, gave evaporated millks that in the majority of cases also showed curdiness, no real comparison could be made as to the relative merit of the alcohol and acid tests.

Table 3 shows the result of the work done at Factory $\mathbf{A}$ on individual patrons' milk samples. Of the 22 samples of raw milk showing no reaction with alcohol, 14, after evaporating, showed curdiness at the standard sterilizing temperature used, which happened to be about what was found necessary to insure a safe-keeping milk, while 8 showed no curdiness. Of the 12 samples of raw milk showing coagulation with alcohol, all showed curdiness after they were evaporated and subjected to the standard sterilizing temperatures.

TABLE 3.-Relation of aleohol test and titratable acidity in Factory A. Evaporated mill having close to 18.15 per cent solius not fat. Effect of sterilization noted after siaking for 1 minute.

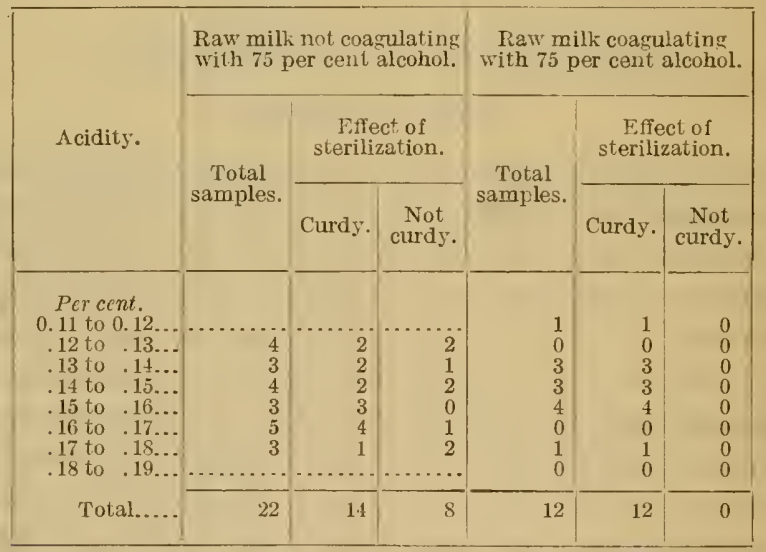

The alcohol test was further tried out on a commercial basis in this plant. The individual cans of milk received at the intake were tested with alcohol according to the method already described. All the milk showing no coagulation with alcohol was run in a separate rat and condensed in the large factory pan as a separate batch. 
A composite sample of the milks showing coagulation with alcohol, along with a sample of that showing no coagulation, was run in the laboratory apparatus as a means of comparison. Out of 4 trials the raw milk showing coagulation with alcohol gave an evaporated milk that in all 4 cases showed curdiness after sterilization at the standard temperature, while the evaporated milk from the raw milks showing no coagulation with alcohol showed curdiness in 3 out of 4 cases. The 4 batches of milk, the individual cans of which showed no coagulation with alcohol and which were run in the large factory pan, all showed curdiness after sterilization. Sereral laboratory runs made on milk taken from the large receiving vat at different times, to get representative samples of the milk received, failed in all instances to give an evaporated milk that would meet the required standard and not show curdiness after sterilizing and shaking.

The general failure of milk, accepted on the acid test at this condensery, to withstand the necessary heat after being evaporated, suggested that it might be due to a deficiency in the composition and balance of milk salts, as reported by Sommer and Hart (2). The fact that the addition of a small amount of dibasic potassium phosphate, which is a normal constituent of milk, corrected the excessire tendency of the milk to curdle in sterilization indicates that this assumption was correct.

Consideration of the manner in which milk at this plant was handled, in connection with the results obtained, indicates that the conditions were quite different from those that the average condensery has to contend with, and for this reason it appeared highly desirable to try out the alcohol test at another place.

\section{WORK AT FACTORY B.}

The work was then continued in a condensery, designated Factory $B$, located in a region where dairying forms a minor part of the farm operations. Is a result of this condition the milk received was not of good quality. All the work done at this plant was on a commercial basis, the milk being graded at the intake and run into separate tanks according to its reaction with alcohol. Separate runs of the milk showing, respectively, coagulation and no coagulation with alcohol, were made in the factory pans, and after retaining the required amount of each batch of evaporated product for the experimental work, they were mixed in one tank and handled in the usual manner by the factory. Because of the small proportion of milk received that showed coagulation with alcohol, the batches from this kind of milk were smaller and in some cases it was necessary to hold them over until the next day in order to get enough for a run in the 
factory pan. When this was found necessary the milk was cooled to a very low temperature and held in that condition overnight; only a very slight increase in acidity was shown.

The evaporated milk from each run was standardized to show close to 18.15 per cent solids not fat. The samples from the raw milk showing no coagulation with alcohol were standardized to show slightly above this figure. All samples were sterilized in one of the large Fort Wayne sterilizers used regularly by the condensery.

Four trials of grading and condensing milk on a commercial basis were made in this factory. The evaporated milk from the raw milks showing no coagulation with alcohol in all cases came through the sterilization process in fine shape, producing no curdiness and indicating that they would have stood more heat; in all four cases, also, the evaporated milk from raw milks showing coagulation with alcohol gave a pronounced curdiness that could not be removed by prolonged shaking.

TABLE 4.-Results obtained by grading with the alcohol test at Factory $B$.

\begin{tabular}{|c|c|c|c|c|c|}
\hline \multicolumn{2}{|c|}{ Raw milk. } & \multirow{2}{*}{ Acidity. } & \multirow{2}{*}{$\begin{array}{l}\text { Reaction } \\
\text { to alco- } \\
\text { hol. }\end{array}$} & \multirow{2}{*}{$\begin{array}{l}\text { Sclids } \\
\text { not fat } \\
\text { in evap- } \\
\text { orated } \\
\text { milk. }\end{array}$} & \multirow{2}{*}{$\begin{array}{l}\text { Steriliza- } \\
\text { tion of } \\
\text { evaporat- } \\
\text { ed milk. }\end{array}$} \\
\hline $\begin{array}{l}\text { Batch } \\
\text { No. }\end{array}$ & Weight. & & & & \\
\hline $\begin{array}{l}1 \ldots \\
2 \ldots \\
3 \ldots \\
4 \ldots \\
5 \ldots \\
6 \ldots \\
7 \ldots \\
8 \ldots\end{array}$ & $\begin{array}{r}\text { Pounds. } \\
12,400 \\
4,250 \\
10,100 \\
9,100 \\
11,500 \\
9,100 \\
12,400 \\
6,300\end{array}$ & $\begin{array}{r}\text { Percent. } \\
0.140 \\
.170 \\
.150 \\
.175 \\
.165 \\
.175 \\
.145 \\
.160\end{array}$ & $\begin{array}{l}\frac{5}{ \pm} \\
\frac{+}{5} \\
\frac{ \pm}{+}\end{array}$ & $\begin{array}{r}\text { Percent. } \\
17.96 \\
17.06 \\
18.53 \\
18.16 \\
18.24 \\
18.16 \\
18.25 \\
17.91\end{array}$ & $\begin{array}{l}\text { No curd. } \\
\text { Curdy. } \\
\text { No curd. } \\
\text { Curdy. } \\
\text { No curd. } \\
\text { Curdy. } \\
\text { No curd. } \\
\text { Curdy. }\end{array}$ \\
\hline
\end{tabular}

Table 4 gives the data on the four trials of grading and condensing at this establishment. The titratable acidity of the lots of milk showing coagulation with alcohol is somewhat higher than that of the milk showing no coagulation with alcohol. We have no definite data that will enable us to say this difference in acidity would account for the difference in coagulation. In order to throw some light on this question, four cans of the sterilized milk were sent to the Jaboratory where the hydrogen-ion concentration or true acidity was determined with the following results: ${ }^{3}$

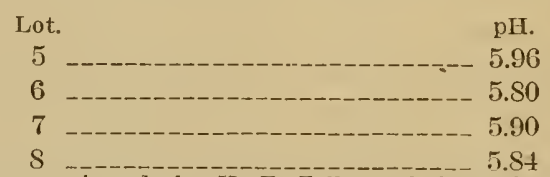

3 The determinations were made by II. F. Zoller, of the Dairy Division. 
While in each case the real acidity of the lot coagulating with alcohol and curdling in sterilization is higher, the difference is so small that it is very doubtful if it would more than counteract the effect of the higher solids of the corresponding lot.

\section{CONCLUSIONS.}

1. The acid test as ordinarily used will reject a portion of the unsatisfactory milks, but as a whole it is unreliable and inadequate as a means of determining the quality of milk for condenseries where evaporated milk is manufactured.

2. There is no direct relation between the coagulation of milk with alcohol and its titratable acidity, but milks high in titratable acidity as a result of fermentation will in the large majority of cases show coagulation with alcohol.

3. The alcohol test shows good possibilities as a practical and reliable test for determining the quality of milk for condenseries making eraporated milk. How generally the test can be applied will require further inrestigation at other condenseries. It is believed that it can be used to advantage in a large majority of average factories.

\section{LIST OF REFERENCES.}

(1) RICE, Frank E.

1919. Milk with high apparent acidity. In Science, N. S., v. 50, no. 1296, p. 424.

(2) Sommer, H. H., and Hart, E. B.

1919. The heat coagulation of milk. In Jour. Biol. Chem., v. 40, no. 1, p. $137-151$.

(3) Auzinger, August.

1909. Studien über die Alkoholprobe der Milch, ihre Verwendbarkeit zum Nachweis abnormer Milchen und ihre Beziehungen zu anderen Prüfungsmethoden pathologischer Milch. In Milchw. Zentbl., r. 5, no. 7 , p. $293-315$; no. 8 , 1. 352-370; no. 9 , p. 393-413; no. 10 , p. $430-446$.

(4) Ayers, S. Henry, and Joirnson, William T., Jr.

1915. The alcohol test in relation to milk. U. S. Dept. Agr., Bul. no. 202. 
